\title{
Impact of Companies' Characteristics on the Relationship between Corporate Social Responsibility Disclosure and Corporate Financial Performance -An Empirical Analysis
}

\author{
SAYEED ZAFAR QAZI ${ }^{1}$, PARVESH KUMAR ASPAL ${ }^{2}$ \\ ${ }^{1}$ Department of HRM, UNIVERSITY OF BUSINESS AND TECHNOLOGY, SAUDI ARABIA, E-mail: sayeed@ubt.edu.sa \\ ORCID: http://orcid.org/0000-0003-1458-3166 \\ ${ }^{2}$ Department of Finance \& Accounting, IKG PUNJAB TECHNICAL UNIVERSITY, INDIA, E-mail: pk_aspal@yahoo.com
}

\begin{abstract}
Strategic managers are persistently accosting with the decision of switching the scared corporate resource for the community welfare to balance the shareholders' and multiple stakeholders' interests. Corporate houses are presumed to not only intensify the economic priorities of investors, but must also consider the community and environmental ramifications as well. Presently, corporations are in dilemma over whether investment in corporate social responsibility (CSR) initiatives will be a cost or gain from an economic point of view. For this purpose, the association between CSR disclosure and corporate financial performance has been empirically explored and also the company characteristic has been considered as a significant and interesting factor influencing the association between CSR and corporate financial performance. The prime objective of the present paper is to examine the impact of companies' characteristics i.e., Age of company on the relationship between corporate social responsibility disclosure and corporate financial performance. Panel data regression statistical technique has been applied to investigate and analyze the relationship. The findings of the study reveal that companies CSR have significant influence on their financial performances. But, on the other hand the company characteristic, age of the company has no significant impact on the corporate financial performance. The findings are found consistent with earlier studies, which validate the company's venture in undertaking the CSR initiatives. The present study addresses theoretical as well as empirical support and inspiration for the corporations towards CSR initiatives.
\end{abstract}

Keywords: Corporate Social responsibility; Stakeholders; Financial Performance; Disclosure and Social; Responsibility; Company Age.

JEL Classification: M10, M14, G39

Received: April 06, 2021

Accepted: June 06, 2021 


\title{
Impacto de las Características de las Empresas en la Relación entre la Divulgación de la Responsabilidad Social Corporativa y los Resultados Financieros de las Empresas - Un Análisis Empírico
}

\author{
SAYEED ZAFAR QAZI ${ }^{1}$, PARVESH KUMAR ASPAL ${ }^{2}$ \\ ${ }^{1}$ Department of HRM, UNIVERSITY OF BUSINESS AND TECHNOLOGY, SAUDI ARABIA, E-mail: sayeed@ubt.edu.sa \\ ORCID: http://orcid.org/0000-0003-1458-3166 \\ 2Department of Finance \& Accounting, IKG PUNJAB TECHNICAL UNIVERSITY, INDIA, E-mail: pk_aspal@yahoo.com
}

\begin{abstract}
RESUMEN
Los gestores estratégicos se enfrentan constantemente a la decisión de cambiar los temidos recursos corporativos por el bienestar de la comunidad para equilibrar los intereses de los accionistas y de las múltiples partes interesadas. Se supone que las empresas no sólo deben intensificar las prioridades económicas de los inversores, sino que también deben considerar las ramificaciones comunitarias y medioambientales. Actualmente, las empresas se encuentran en el dilema de si la inversión en iniciativas de responsabilidad social corporativa (RSC) será un coste o una ganancia desde el punto de vista económico. Para ello, se ha explorado empíricamente la asociación entre la divulgación de la RSE y los resultados financieros de las empresas, y también se ha considerado que las características de la empresa son un factor significativo e interesante que influye en la asociación entre la RSE y los resultados financieros de las empresas. El objetivo principal del presente trabajo es examinar el impacto de las características de las empresas, es decir, la edad de la empresa, en la relación entre la divulgación de la responsabilidad social corporativa y el rendimiento financiero de las empresas. Se ha aplicado la técnica estadística de regresión de datos de panel para investigar y analizar la relación. Los resultados del estudio revelan que la RSE de las empresas tiene una influencia significativa en sus resultados financieros. Pero, por otro lado, la característica de la empresa, la edad de la empresa, no tiene un impacto significativo en el rendimiento financiero de las empresas. Los resultados son coherentes con estudios anteriores, que validan la aventura de la empresa al emprender las iniciativas de RSE. El presente estudio ofrece apoyo teórico y empírico y sirve de inspiración a las empresas para emprender iniciativas de RSE.
\end{abstract}

Palabras claves: Responsabilidad social de las empresas; Grupos de interés; Rendimiento financiero; Divulgación y responsabilidad social; Edad de la empresa.

JEL Classification: M10, M14, G39

Recibido: 06 de abril de 2021

Aceptado: 06 de junio de 2021 


\section{Introduction}

Business managers around the globe are progressively confronting a new challenge to behave socially and ethically responsible attitude to contribute towards the constructive progress of the community. The CSR is a notion that associates the community with the corporate world and represents a commitment between the community and the companies (Wood, 1991). In 1919, the concept of CSR was vaguely structured in terms of morals and ethics, and shareholders had no idea how their interest had been delivered. But in the year 1999, the meaning and business implication of CSR was much more tempting and acceptable to shareholders (Lee, 2008). In the 21st century, corporations around the globe have recognized numerous challenges regarding their prosperity and sustainability. The revolution in the business domain has sparked the corporations to assimilate CSR initiatives in their strategic policies to meet such new millennium challenges (Silberhorn and Warren, 2007). During recent years, CSR has emerged as one of the most orthodox and extensively accepted concepts in the corporate world (Carroll and Shabana, 2010). Academics and business managers have acknowledged that how corporate social responsibility has been mutated from a doubtful and vague concept to a high-ranking topic on research schema (McWilliams et al. 2006). Now corporations have realized that for the success of a business, it is required to switch their resources towards the promotion of community betterment, environmental safety, gender equality and, poverty \& hunger eradication under CSR compliance (Pava and Krausz, 1996).

It is a general conviction that corporate houses and business managers may ingenuously be considered as the trustees of stockholders (Berle, 1931). Corporations are required to maintain a balance between the shareholders' and multiple stakeholders' interests. Apart from the wealth maximization of investors, corporations should also be responsible for the expectations of society, employees, suppliers, customers, and the government (Johnson, 1971). CSR activities undertaken by the corporation represent the impact of its operations on the stakeholders' quality of life. Thus, CSR is the combination of all those activities, which have been initiated by the corporate sector for community welfare (Banerjee, 2008). CSR is the assimilation of corporate policies and ethical business operations that consider the interests of all stakeholders including environment protection \& safety (Smith, 2002). CSR encompasses the ethical, legal, economic, and discretionary responsibilities of the corporations, which have to be discharged towards various stakeholder groups (Maignan and Ferrell, 2000).

Presently, corporations around the globe are not contemplating CSR expenditures as a cost, but it is considered as a strategic mechanism to boost up the efficiency, retention of talented employees, and to inspire the managers CSR initiatives facilitate the corporations to gain a constructive corporate image which is a supportive and essential determinant for sustaining corporate growth. The CSR initiatives have a strategic advantage to the companies by acknowledging the community expectations, which will facilitate sustainable business operations, and endorse transparency and accountability (Bissoon, 2018). Moreover, the effective management of CSR activities facilitates the corporations to have a competitive edge over their rivals by way of enlarged customer base, improved R\&D, talented workforce, and relations with the state (Weiser and Zadek, 2000). The outcomes of PricewaterhouseCoopers survey 2002 witnessed that about 70 per cent corporate managers believed that acknowledging CSR has a considerable influence on the corporation's profits (Simms, 2002). As a matter of CSR disclosure and corporate financial performance association is concerned, it has been observed that CSR has an explicit influence on companies' profitability.

The profitability of the company may be influenced by various factors company size, productivity, industry affiliation, and the age of the company (Margaretha and Supartika, 2016). The theory of learning by doing reveals that as the age of the company increases, there is the possibility of improvement in their productive efficiency over a period of time by learning from their experience (Bahk and Gort, 1993). The company's age may be a vital factor in financial performance. Previous research 
studies revealed that the probability, growth, failure, and the variability of companies' growth depend upon the age of the company (Yasuda, 2005). It has been observed that the company's age has a direct influence on the companies' profitability (Ilaboya and Ohiokha, 2016). The older companies enjoy higher productivity and profits, as the profitability of the company is influenced by its age. Furthermore, this crucial concern is as yet being ignored with regards to the developing nations, despite the fact that at the globe level the extensive consciousness concerning the environmental and societal responsibility issues has been realized. In order to identify the CSR disclosure and financial performance association, and the influence of company age on this relationship, the present study has been explored.

\section{Review of Literature}

The notion of CSR has lingered under the deliberations since its inception. The opponents of the social activities suggested that management should optimally utilize the corporate resources for the wealth maximization of shareholders, instead of spending on social activities (Friedman, 1970). Whereas, the proponents of CSR have supported that the corporations believe in ethical practices that must undertake social responsibility and should contribute some of their resources for the development and betterment of society. Such social initiatives, in turn, will enhance the corporate reputation, retaining of talented workforce, better community relations, and long-run profitability (Davis, 1973). The concept of stakeholder theory has germinated gradually in the 1960s and attained a swift momentum since the 1980s. The contributing efforts of (Freeman, 2010) instigated the formal evolution of stakeholder theory, which further originated the public consciousness about CSR. The underlying aspect of CSR is to perform manifold CSR initiatives for stakeholder groups such as community, investors, government, managers, employees, traders, and consumers, etc. These stakeholders watch out the interests of the corporations, and in turn, the corporations defend the stakeholders' interests invisibly.

The critical underlying principle behind the ambiguity about the CSR disclosure and financial performance association is the serious difficulty in the measurement of CSR disclosure. It is a multifaceted construct hinge on a wide range of inputs such as social initiatives for community, service \& product quality, environmental protection, women empowerment, and customer relationship management (Wood, 1991). CSR disclosure measurement techniques used in the earlier research works were based on arbitrary choice (Aupperle et al., 1985). These techniques were Fortune social responsibility index, Moskowitz's reputational index, and case studies method (Bowman and Haire, 1975; Preston and O'Bannon, 1997, Clarkson, 1995). After considering the above issues, a multifaceted CSR disclosure measurement based on stakeholder theory (Davenport, 2000; Wartick and Cochran, 1985; Wood, 1991) has been employed in the present study. The present study adopts a study of (Hackston and Milne, 1996) encompassing the dimension of social issues, employee issue, service and product quality, and environmental protection \& energy conservation issues. So in the present study, the prime CSR disclosure dimensions such as Employee relations, Consumer issues and products, Community welfare and development, and Environmental issues are used to extract the CSR disclosure information from the annual reports.

The review of earlier research work revealed that a lot of research studies investigated the CSR disclosure and corporate profitability relationship. Numerous researchers have investigated several research studies following different methodologies and techniques. Waddock and Graves (1997), Preston and O'Bannon (1997), Peters and Mullen (2009) and Saleh et al., (2010) explored the CSR disclosure and corporate profitability relationship and their studies revealed that CSR has a direct influence on profitability. It has been observed that investing in CSR practices will enhance the corporate profitability and in turn, the positive impact on the profitability motivates the companies to invest in CSR initiatives, because of availability of sufficient resource to settle the community issues. Moreover, CSR initiatives have positive and long-term impacts on the financial benefits of corporations (Waddock and Graves, 
1997). As well, the research findings on this association have reported positive and mixed findings (Posnikoff, 1997; Orlitzky, Schmidt and Rynes, 2003), and negative (Wright and Ferris, 1997). Similarly, Dkhili and Ansi (2012) investigated the CSR and corporate profitability relationship of the companies and revealed a positive impact on corporate profitability. Similarly, Bowman and Haire (1975); Sturdivant and Ginter (1977) observed a positive relationship in their research investigation.

The company age is considered as significant determinant that can influence the CSR disclosure and profitability relationship (Schreck, 2011). Younger companies do not have much concentrate on CSR initiatives. After gaining a sound financial position, corporations may move towards CSR investment to enhance their reputation (Peloza, 2006). Younger companies may perform better as compared to older counterparts. Whereas, older companies may own distinct expertise and talents as compared to younger companies, which in turn, facilitate them to develop rapidly and attain more profitability (Sidhu and Bhatia, 1993). However, older companies are more reluctant to adopt the latest technologies in a dynamic environment, which may result in failure of the same (Hannan and Freeman, 1989). Similarly, Milosevic (2018) examined the profitability determinants of companies and found that age has indicated a minuscule influence on the profits. Banchuenvijit (2012) examined the effects of the company age on the profitability of Vietnam listed companies and found an insignificant association between company age and ROE.

From the above discussion on the literature of existing research studies, it has been observed a positive association between companies' financial performance and CSR disclosure; and the age of the company has an influence on this relationship. But, the various other determinants like industry nature, company size, measurement technique of CSR disclosure and time period, etc. are the overriding reasons behind diversifying results. Therefore, in the present study, by employing rich source of data on CSR disclosure and broad base multi-dimensional CSR disclosure index, the present research work represents an explicit study on the empirical association between CSR disclosure and corporate profitability and the impact of company characteristics on this relationship.

\subsection{Need and Importance of the Study}

India has an affluent and long saga of political, cultural, economic, and social attributes; which is quite unique as compared to the other nations in regard to business ethics and moral values. Although, these attributes could give a decent chance to examine the significance and impact of CSR in such a nation (Tsang, 1998). CSR has emerged as a burning topic among Western management communities, and there are diverse schools of thought with monotonous contention over what, why and how is CSR. On the other hand, presently, the academicians and corporate world have initiated to look further empirically the influence of CSR disclosure on profitability (Chen and Wang, 2011). In regard to the CSR disclosure in the Indian corporate environment, the companies as well as the community both are lacking about their responsibilities and privileges. India is a developing nation in regard to CSR awareness among the public and corporate sectors. Moreover, a little research work has been explored in this regard and Indian companies feel hesitation in discharging social obligations due to the lack of apparent directions. Companies are assuming CSR expenditure as an obligation rather than an opportunity for long-standing benefits. However, there is still a need to create an awareness of the long-term benefits of CSR initiatives on the profitability and general public. The companies are required to think about their responsibilities towards the community in which they exist, rather than the profit maximization for shareholders.

Therefore, the present study has attempted to use stakeholder theory to measure the CSR disclosure and investigated its association with the profitability of companies in the Indian context. Moreover, the company characteristic has been considered as a significant and interesting factor influencing this association. The life expectancy of the company enhances with the passage of time as it becomes older (Dunne, Roberts and Samuelson, 1989) and it facilitates better companies' survival (Baker and Kennedy, 
2002). So, the present study has also investigated the impact of company characteristic, i.e. company age on the relationship between CSR disclosures and financial performance.

\subsection{Objectives of the Study}

The prime objective of the present research study is to:

1. Investigation of the impact of companies' characteristics on the CSR disclosure and corporate financial performance association.

\section{Database and Research Methodology}

To fulfill the objective of the present research work, the financial data of the sample companies have been collected from the Prowess database. The information concerning the disclosure of CSR activities has been extracted from corporate sustainability, annually and environmental reports. The time period for the current study is of three years i.e. from the year 2014 to the year 2016. This specific time period has been picked in light of the fact that in 2013 a recorded historical amendment has been made in Companies Act, 1956 in regard to the mandatory discharge of social responsibility. 81 companies registered on the Indian Bombay Stock Exchange have been drawn as a sample and are categorized on the basis of industry classification, such as (1) Drugs and Pharmaceuticals, (2) Automobile, (3) Paint, Chemical, Leather and Pesticides, (4) Communication equipment and computer software, (5) Energy, (6) Oil and Gas, (7) Infrastructure, (8) FMCG, (9) Mineral and Metal and (10) Textile.

\subsection{Research Design}

To extract the degree and nature of CSR disclosure information, a CSR checklist containing thirty CSR disclosure statements has been prepared by following the earlier studies of Haniffa and Cooke (2005), Peters and Mullen (2009), Rouf (2011), and Valmohammadi (2014). Following the stakeholder theory, such thirty statements have been further categorized under four main dimensions; that is (1) Development and welfare of society (2) Employee relations (3) Customer issues and products and (4) Environmental issues. The CSR disclosure sheet is computed on the basis of data extracted from sustainability, annual and environmental reports of the sample companies by applying content analysis technique (Bowman and Haire, 1975; Abbott and Monsen, 1979). For the present study, a panel data regression has also been employed to estimate the regression equation. The panel data regression statistical technique is concerned with the grouping of time series and cross-sectional dimensions concomitantly to create efficient estimates

\subsection{Model Specification}

Figure 1 Research Framework

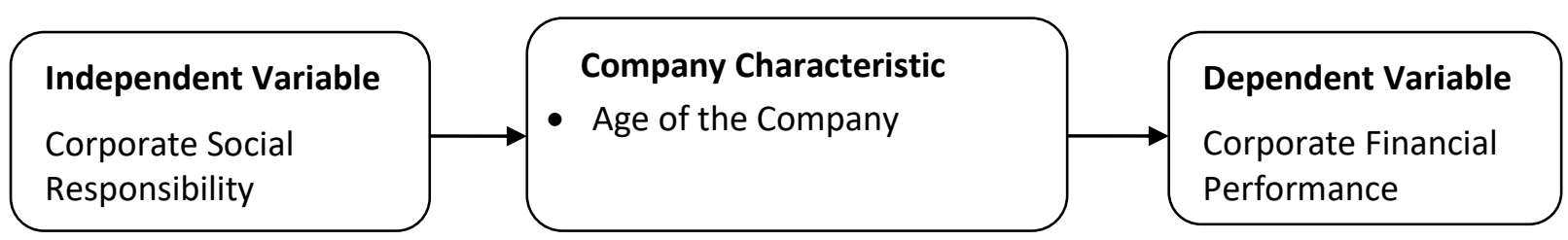




\subsubsection{Dependent Variable Description}

On reviewing the literature, it has been observed that the two determinants of financial performance, such as return on equity (ROE) and return on assets (ROA) have been widely used. The application of ROA and ROE as determinants of financial performance is in consonance with several of the earlier research work, which explored the CSR and corporate financial performance relationship (Hull and Rothenberg, 2008). In the current study, these two financial performance measurement indicators are in line with the research work of Waddock and Graves (1997). A number of researchers, for instance, Stanwick and Stanwick (1998); Oeyono, Samy and Bampton (2011); Adjei (2012) used ROA as a determinant of financial performance in numerous studies. Similarly, studies of Brigham and Daves (2007) and Atmaca and Demirel (2017) have employed ROE to assess financial performance.

\subsubsection{Independent Variable Description}

In the various empirical investigations, numerous researchers have revealed that a better corporate social responsibly escorts to better financial performance. Profitability is assumed as a considerable feature which influences corporate growth and existence. Smith (2007) expressed that the companies have spent in societal issues for earning a competitive advantage over their rivals, and also highlighted the positive association between CSR disclosure and companies' profitability. The present study attempts to explain the effects of company characteristics, age of the company on the association between CSR disclosure and the financial performance. Company age is a significant determinant that can influence the CSR disclosure and profitability relationship (Schreck, 2011). The age of the company may be significant companies' characteristic that may affect CSR disclosure reporting (Peloza, 2006). Therefore, in the present study, the CSR disclosure and company age have been employed as independent variables.

\subsubsection{Control Variables Description}

The review of literature further advocates that the CSR disclosure and corporate profitability association is also affected by numerous other variables; therefore, it turns up significant control of these variables while investigating the relationship. Nevertheless, in the current study, the control variables such as leverage (Brammer and Pavelin, 2008; Reverte, 2009; Andrikopoulos and Kriklani, 2012) and size of the company (Griffin and Mahon, 1997; Waddock and Graves, 1997, McWilliams et al., 2006) are employed in the same approach as that of independent variables.

\subsection{Econometric Specification}

With a view to examining the effects of the companies' characteristics, age of the company on CSR disclosure and corporate profitability in the light of control variables of the sampled Indian companies, the panel data regression equations have been estimated as follows:

$$
\begin{aligned}
& R O E_{i t}=\alpha_{0}+\beta_{1} C_{C S} \text { it }+\beta_{2} A_{G G} i t++\beta_{3} S_{I Z E} i t+\beta_{4} L E V_{i t}+e_{i t} \\
& R O A_{i t}=\alpha_{0}+\beta_{1} C S R_{i t}+\beta_{2} A G E_{i t}++\beta_{3} S_{I Z E} \text { it }+\beta_{4} L E V_{i t}+e_{i t}
\end{aligned}
$$

Where,

$$
\begin{aligned}
& \text { ROE }=\text { Return on Equity } \\
& \text { ROA }=\text { Return on Assets. } \\
& \text { CSR }_{\text {it }}=\text { Company CSR Disclosure } i \text { at time } t \\
& \text { AGE }_{\text {it }}=\text { Company Age } i \text { at time } t
\end{aligned}
$$




$$
\begin{aligned}
& \text { SIZE }_{\mathrm{it}}=\text { Company Size } i \text { at time } t \\
& \mathbf{L E V}_{\mathrm{it}}=\text { Leverage } i \text { at time } t
\end{aligned}
$$

\section{Data Analysis and Interpretation}

The Panel data regression technique has been applied to examine the effects of companies' characteristics, age of the company on the CSR disclosure and companies' profitability association in the light of control variables. For this purpose, the validity of various regression assumptions has been checked and specification tests have been applied. The regression analysis has been estimated using three models such as the Pooled Ordinary Least Squares (OLS), The Fixed Effects Model (FEM), and The Random Effects Model (REM). These three estimation models have been compared to find the best fit model using the two specification tests such as the Redundant Fixed Effect test and the Hausman test.

\subsection{Diagnostic Tests}

The various underlying regression assumptions have been complied with to validate the regression model. The various diagnostic tests are used to examine the presence of Multicollinearity, Homoscedasticity, Autocorrelation, and Stationarity in the regression models which may have an impact on the efficacy of the estimators.

For assessing the multicollinearity problem, the VIF values of all independent variables have been examined. The average VIF value of 1.19 signifies that there is no multicollinearity problem. In addition to this, the value of Pearson correlation coefficients between independent and dependent variables has been found lower than the standard. So, results reveal that there is no problem of multicollinearity. The assumption of Homoscedastic has also been examined and it has been found that data is not Heteroscedastic. In the present study, the regression assumption of Autocorrelation has also been examined. In the present study, the values of the Durbin - Watson (DW) statistic of the independent variables ROE and ROA are 2.25 and 2.40 respectively, which signifies that there is no autocorrelation among the variables. Furthermore, the Augmented Dickey-Fuller test is used to assess the unit root problem in the data and found that data is stationary.

\subsection{Specification Tests for Regression Model}

For the selection of an appropriate regression model for the analysis of data, the specification tests for all related regression models have been applied. The Redundant Fixed Effect test has been applied to choose an appropriate model between the Panel data regression and the Pooled OLS regression. For this principle, period effects, cross-section, and total effects have been evaluated. In the case of independent variables ROE and ROA, the statistical results revealed that the panel data regression is more appropriate and has been preferred over the Pooled OLS model. Similarly, the Hausman specification test is applied to select an appropriate model amid the FEM and the REM and the statistical values reflect that the FEM is preferred over the REM.

\subsection{Empirical Findings of the Regression Model}

The statistical values of specification tests have reflected that the Fixed Effect Model is preferable method for regression analyses. The earlier research investigations have highlighted mixed findings of the CSR disclosures and companies' profitability association. Earlier empirical research studies reported nebulous relations between CSR disclosure and companies' profitability (Shane and Spicer, 1983). Furthermore, Roman, Hayibor and Agle (1999) epitomized the 46 research papers and 51 research studies and reported that 63 percent of studies have supported the positive association, whilst only 10 percent of studies have supported the negative association and 27 percent of studies did not found any 
explicit result. On the same manner, some research investigations have revealed a positive association amid CSR disclosure and long-term corporate profitability performance (Waddock and Graves, 1997; Stanwick and Stanwick 1998).

The life expectancy of the company enhances with the passage of time as it becomes older (Dunne et al., 1989), and it facilitates better companies' survival (Baker and Kennedy, 2002). To assess whether there is a relation amid the company age and corporate profitability, (Villalonga and Amit, 2006) found no relations between these two variables, but a positive association has also been documented by Kipesha (2013) in Tanzania and by Osunsan et al. (2015) in Uganda.

Table 1 Regression Results: ROE and ROA as a Dependent Variable

\begin{tabular}{|c|c|c|c|c|c|c|}
\hline \multirow{2}{*}{$\begin{array}{l}\text { Dependent } \\
\text { Variable } \\
\text { Independent } \\
\text { Variable } \\
\end{array}$} & \multicolumn{3}{|c|}{$\begin{array}{l}\text { Return on Equity } \\
\text { Panel (FEM) }\end{array}$} & \multicolumn{3}{|c|}{$\begin{array}{l}\text { Return on Assets } \\
\text { Panel (FEM) }\end{array}$} \\
\hline & Coefficient & t-Statistic & Prob. & Coefficient & t-Statistic & Prob. \\
\hline CSR & 0.1673 & 2.2991 & $0.022 *$ & 0.0782 & 2.1554 & $0.0326^{*}$ \\
\hline Age & -14.0573 & -1.0019 & 0.317 & 5.6707 & 0.8107 & 0.4187 \\
\hline Leverage & -5.6106 & -1.6212 & $0.107^{* *}$ & -3.3027 & -1.9138 & $0.0574^{*}$ \\
\hline Company Size & -7.0323 & 1.8370 & $0.068 * *$ & 3.8144 & 1.9982 & $0.0474^{*}$ \\
\hline Observations & \multicolumn{3}{|l|}{243} & \multicolumn{3}{|l|}{243} \\
\hline R-squared & \multicolumn{3}{|l|}{0.9197} & \multicolumn{3}{|l|}{0.9192} \\
\hline $\begin{array}{l}\text { Adjusted R- } \\
\text { squared }\end{array}$ & \multicolumn{3}{|l|}{0.8663} & \multicolumn{3}{|l|}{0.58762} \\
\hline F-statistic & \multicolumn{3}{|l|}{19.674} & \multicolumn{3}{|l|}{21.4078} \\
\hline $\begin{array}{l}\text { Prob. (F- } \\
\text { statistic) }\end{array}$ & \multicolumn{3}{|l|}{0.0000} & \multicolumn{3}{|l|}{$0.0000^{*}$} \\
\hline \multicolumn{7}{|c|}{ Redundant Fixed Effect Test } \\
\hline $\begin{array}{l}\text { Chi-Square } \\
\text { Statistic }\end{array}$ & \multicolumn{3}{|l|}{17.156} & \multicolumn{3}{|l|}{15.681} \\
\hline Prob. & \multicolumn{3}{|l|}{0.0000} & \multicolumn{3}{|l|}{0.000} \\
\hline \multicolumn{7}{|l|}{ Hausman Test } \\
\hline Chi-Sq. Statistic & \multicolumn{3}{|l|}{7.031} & \multicolumn{3}{|l|}{12.953} \\
\hline Prob. & \multicolumn{3}{|c|}{$0.134 * * *$} & \multicolumn{3}{|l|}{0.011} \\
\hline
\end{tabular}

${ }^{*}$ Significant at 5 percent level of significance

** Significant at 10 percent level of significance

*** Significant at 20 percent level of significance

The comparative analysis of the statistical results of all models has revealed that the regression coefficients are statistically significant in the Fixed Effects model. It has been found a positive and significant association between CSR disclosure and corporate profitability (ROE and ROA). Further, the high values of adjusted $R$ - square, i.e. 91.97 percent and 91.92 percent in the case of dependent variable ROE and ROA respectively express the overall best fit of the Fixed Effects model. This is further substantiated by F-statistics $(p=0.0000)$ at the 5 percent significance level.

The findings of association among CSR disclosure and companies' profitability determinants (ROA and ROE) in this research work are in concurrence with the earlier research studies. In this regard, numerous investigators like Saleh et al. (2010); Waddock and Graves (1997); Chen and Wang (2011) conducted an investigation on such relations and found a significant and positive association. Similarly, 
Montabon, Montabon, Sroufe and Narasimhan (2007) and Ahamed et al. (2014) conducted their research studies on the association between CSR disclosure and companies' profitability and observed that CSR disclosures have a positive reaction towards the companies' profitability.

As far as the impact of companies' characteristics, i.e. age of the company on the CSR disclosures and corporate profitability is concerned, the results of the present study highlight an insignificant association with profitability determinants ROE and ROA. The results of the present study are in coherence with the studies conducted earlier. Adam, Almeida and Ferreira (2005) in their study about the association amid corporate profitability (ROE) and company age has found a negative and significant association. Similarly, Gaur (2010) observed the impact of several variables, including company age on the operating profits and found that the company age has no significant impact. Rajput and Joshi (2014) conducted a study using panel regression on the relationships between economic performance (ROE) and the company age taking a sample of BSE100 companies. The analysis of the result revealed no significant association. Zulfiqar (2016) conducted a study on corporate philanthropy and companies' profitability in the Pakistani Textile Sector and found that an insignificant association amid company age and ROE.

Similarly, Adam et al. (2005) in their research work found a negative and insignificant association amid companies' performance ROA and company age. In a study in Malaysia, Marimuthu and Kolandaisamy (2009) investigated the influence of the company age on corporate performance (ROA) and found an insignificant relationship between them. Mínguez and Lopez (2010) undertook a study and revealed a negative and insignificant association amid the company's age and performance (ROA). Malik, Liu and Kyriacou (2011) examined the relationship of profitability determinant (ROA) of the Pakistani list companies with the company age and found no association between company age and corporate profitability. Julizaerma and Sori (2012) conducted a study and found insignificant relationships between the company age and corporate profitability measured by ROA. Rajput and Joshi (2014) conducted a study using panel regression on the relationships between economic performance ROA and the company age. The analysis of the result highlighted an insignificant association. Similarly, in a study, Nahusenay (2016) also found that the age of the company has an insignificant influence on companies' financial strength.

\section{Summary Results of the Tested Hypotheses}

For the fulfillment of objectives, the present study has formulated four alternative hypotheses, which have predicted CSR disclosure and companies' financial performance association; and the influence of company age on this association. The hypotheses $\mathrm{H}_{1 A}$ and $\mathrm{H}_{1 B}$ are developed to investigate the CSR disclosures and corporate financial performance relationship. Similarly, the hypotheses $\mathrm{H}_{2 \mathrm{~A}}$ and $\mathrm{H}_{2 \mathrm{~B}}$ have been developed to investigate the influence of company age on the above association.

The table highlights that the regression coefficients of the relationship amid CSR disclosures and ROE is positive (2.2991) and statistically significant. Similarly, regression coefficients of the association between CSR disclosures and ROA are also positive (2.1554) and statistically significant. Thus the hypotheses $\mathrm{H}_{I A}$ and $\mathrm{H}_{1 B}$ are accepted. It implies that CSR disclosures have a positive and significant influence on financial performance determinants ROA and ROE. But, on the contrary, regression coefficients of the relationship among the age of the company and financial performance indicators, ROE $(-1.0019)$ and ROA (0.8107) are statistically insignificant. This reflects that the hypotheses $\mathrm{H}_{2 \mathrm{~A}}$ and $\mathrm{H}_{2 \mathrm{~B}}$ are rejected. So, it implies that the age of the company has no significant influence on profitability. 
Sayeed Zafar Qazi, Parvesh Kumar Aspal

Table 2 Summary of Results

\begin{tabular}{|l|l|l|l|l|}
\hline \multicolumn{2}{|l|}{ Hypotheses } & Description & p-values & Result \\
\hline \multirow{2}{*}{$\mathrm{H}_{1}$} & $\mathrm{H}_{1 \mathrm{~A}}$ & Relationship between CSR and ROE & $\begin{array}{l}\mathbf{0 . 0 2 2} \\
(2.2991)\end{array}$ & Supported \\
\cline { 2 - 5 } & $\mathrm{H}_{1 \mathrm{~B}}$ & Relationship between CSR and ROA & $\begin{array}{l}\mathbf{0 . 0 3 2} \\
(2.1554)\end{array}$ & Supported \\
\hline \multirow{2}{*}{$\mathrm{H}_{2}$} & $\mathrm{H}_{2 \mathrm{~A}}$ & $\begin{array}{l}\text { Relationship between company age } \\
\text { and ROE }\end{array}$ & $\begin{array}{l}\mathbf{0 . 3 1 7} \\
(-1.0019)\end{array}$ & Not Supported \\
\cline { 2 - 5 } & $\mathrm{H}_{2 \mathrm{~B}}$ & $\begin{array}{l}\text { Relationship between company age } \\
\text { and ROA }\end{array}$ & $\begin{array}{l}\mathbf{0 . 1 4 8} \\
(0.8107)\end{array}$ & Not Supported \\
\hline
\end{tabular}

The above findings have been supported by the empirical literature. Acceptance of alternative hypotheses signifies that CSR disclosures have a significant and positive influence on the financial performance of sample companies, whereas, the Age of the company has an insignificant impact on the companies' profitability. Numerous researchers opined that the companies that initiate CSR disclosures have achieved enhanced financial performance; conversely, the companies that do not support CSR practices may suffer adversely from a financial performance point of view (Friedman, 1970). In order to enhance and sustain the financial performance, reputation, and improvement in market share; companies are required to form strategies for CSR initiatives (Adams, 2002). Such CSR practices enhance the legitimacy of the companies and will improve productivity, corporate reputation, and an intense customer base. CSR practices provide a long term competitive edge to the company and have an impact on companies' profitability (Weber, 2008). The adoption of CSR initiatives facilitates the managers to oversee sustainable business organizations (Ganescu, 2012). Moreover, the adoption of CSR activities is a strategic part of change management in modern corporations (Perez and Del Bosque, 2013). By applying stakeholder theory, (Chen and Wang, 2011) explored such association among Chinese companies and expressed that with good CSR, the financial performance has been enhanced. Similarly, Karaye, Ishak and Che-Adam (2014) explored their research works on this relationship and revealed that CSR is positively influenced the financial performance.

Liargovas and Skandalis (2008) explored the profitability and company age association revealed that companies' financial performance is not influenced by companies' age. Gurbuz, Aybars and Kutlu (2010) used panel data analysis on a sample of 164 companies' and demonstrated an insignificant association amid the company age and profitability. Margaretha and Supartika (2016) examined factors affecting profitability, like company age, productivity, and industrial affiliation of the Indonesian companies. The result indicated a negative and insignificant influence between company age and profitability. Ahmed, Hillier and Tanusasmita (2011) specifically examined the effects of the company-specific factor such as age on profitability and observed an insignificant association amid company age and profitability. Charles, Ahmed and Joshua (2018) examined the effect of company characteristics on the profits of Nigerian companies and revealed that the company age has an insignificant impact on the profits of sampled companies.

\section{Discussion and Conclusion}

Basically, the corporate sector around the globe is reluctant and apprehensive in embarking the CSR investment, as there is constant suspicion over the economic outcomes of CSR activities. Although contrary to this, the literature review implies that investment in CSR activities has not only to improve the financial performance but also improved the corporate reputation, enhanced productivity, and retention of a talented workforce. The corporations with improved CSR initiatives have the advantage of enhanced corporate reputation, customer loyalty, and enlarged customer base. The CSR scheme hinges upon the interdependence between the corporate sector and society, so companies must consider the 
long-run impact of its economic operations on social and environmental concerns. Investment in CSR activities provides a better prospect for extracting economic benefits. The profits so earned provide incentives, which facilitate the companies to maintain their status. The company age is a significant determinant that may influence the CSR disclosures and profitability association. In concurrence with the outcomes of earlier research studies that revealed positive relationships, the present study has attempted to address the perennial question of the impact of company characteristics on the association amid CSR disclosure and companies' financial performance. The findings of the study reveal that corporate financial performance does depend on CSR disclosure with a sign of positive relationships, so the findings are in consonance with the empirical literature, which reflects that companies' CSR practices are consistent with the claims of stakeholder theory. In this way, profitable companies can redirect their additional financial resources towards the community betterment.

In addition to this, it has also been observed that the company age has an insignificant impact on profitability. The literature has reported several reasons for the insignificant role of age on the companies' financial performance. Age reduces flexibility and discourages change over a period of time. Concurrently, whatever the company gains from its established business may probably deteriorate with the passage of time. Moreover, the organizational inertia prevailing in older companies results in inflexibility to adapt themselves to the changes arising from the dynamic business environment. The older companies are incapable to solve collective action problems due to the presence of organizational rigidity. Due to the organizational rigidness, older companies cannot compete with their rivals; because of high-cost factors, obsolete techniques, and fewer R\&D initiatives. In addition to this, companies' performance deteriorates with the passage of time due to a lower rate of productivity and turnover. Moreover, the age of the companies has a negative influence on their performance, because, as companies become older, the advantages of their collective learning and expertise diminish due to their inertia, inflexibility, and rigid organizational structure.

In spite of the above, although it requires the corporate sector to invest resources for socially responsible initiatives, as it fulfills the need of each stakeholder group, which in turn ensures good financial results. Accordingly, the internal stakeholders will devote ethical inputs for the betterment of companies and in turn, the external stakeholder groups will refurbish a good corporate image. Such a good corporate image will attract more customers, investors and talented workforce, which will ultimately lead to improved growth and financial performance. Circumstantially, the company with additional profits and resources will be self-motivated for undertaking socially responsible initiatives, which will boost the company and stakeholder relationship, thus promoting enhanced financial performance and improved society's standard of living. Moreover, enhanced profitability may improve companies' reputations, investor relations, customer loyalty, employee morale, and avoid penalties for environmental issues.

\section{References}

1. Abbott, W. F., \& Monsen, R. J. (1979). On the measurement of corporate social responsibility: Selfreported disclosures as a method of measuring corporate social involvement. Academy of Management Journal, 22(3), 501-515. doi:10.5465/255740.

2. Adams, C. A. (2002). Internal organizational factors influencing corporate social and ethical reporting: Beyond current theorizing. Accounting, Auditing \& Accountability Journal, 15(2), 223-250. doi:10.1108/09513570210418905

3. Adams, R. B., Almeida, H., \& Ferreira, D. (2005). Powerful CEOs and their impact on corporate performance. The Review of Financial Studies, 18(4), 1403-1432. https://doi.org/10.1093/rfs/hhi030 
4. Adjei, F. (2012). Debt dependence and corporate performance in a financial crisis: evidence from the sub-prime mortgage crisis. Journal of Economics and Finance, 36(1), 176-189. doi:10.1007/s12197010-9140-0.

5. Ahmed, K., Hillier, J., \& Tanusasmita, E. (2011). R\&D profitability, intensity and market-to-book: evidence from Australia. Accounting Research Journal, 24(2), 150-177. doi: 10.1108/10309611111163691..

6. Andrikopoulos, A., \& Kriklani, N. (2013). Environmental disclosure and financial characteristics of the firm: The case of Denmark. Corporate Social Responsibility and Environmental Management, 20(1), 55-64. doi: 10.1002/csr.1281

7. Atmaca, M., \& Demirel, E. (2017). Economic Impact on Financial Ratios of Food Industry at Istanbul Stock Exchange Listed Firms. International Journal of Economics and Financial Issues, 7(3), 537-541. Retrieved from https://search.proquest.com/openview/aa7d80aa1288be4c3e30ad5c945af611/1?pqorigsite $=$ gscholar $\& \mathrm{cbl}=816338$

8. Bahk, B. H., \& Gort, M. (1993). Decomposing learning by doing in new plants. Journal of Political Economy, 101(4), 561-583. http://dx.doi.org/10.1086/261888

9. Baker, G. P., \& Kennedy, R. E. (2002). Survivorship and the economic grim reaper. Journal of Law, Economics, and Organization, 18(2), 324-361. https://doi.org/10.1093/jleo/18.2.324

10.Banchuenvijit, W. (2012). Determinants of firm performance of Vietnam listed companies. Academic and Business Research Institute, 1-7. Retrieved from http://aabri.com/SA12Manuscripts/SA12078.pdf

11.Banerjee, S. B. (2008). Corporate social responsibility: The good, the bad and the ugly. Critical sociology, 34(1), 51-79. http://dx.doi.org/10.1177/0896920507084623

12.Berle, A. A. Jr (1931). Corporate powers as powers in trust. Harvard Law Review, 44, 1049-1076. doi: $10.2307 / 1331341$

13.Bissoon, O. (2018). Corporate social responsibility in Mauritius: an analysis of annual reports of multinational hotel groups. Asian Journal of Sustainability and Social Responsibility, 3(1), 2. https://doi.org/10.1186/s41180-017-0017-4

14.Bowman, E. H., \& Haire, M. (1975). A strategic posture toward corporate social responsibility. California Management Review, 18(2), 49-58. https://doi.org/10.2307/41164638

15.Brammer, S., \& Pavelin, S. (2008). Factors influencing the quality of corporate environmental disclosure. Business Strategy and Environment, 17(2), 120-136. https://doi.org/10.1002/bse.506

16.Brigham, E. F., \& Daves, P. R. (2007). Intermediate Financial Management (Ninth Edition). OH, USA: Thomson Higher Education.

17.Carroll, A. B., \& Shabana, K. M. (2010). The business case for corporate social responsibility: A review of concepts, research and practice. International Journal of Management Reviews, 12(1), 85-105. https://doi.org/10.1111/j.1468-2370.2009.00275.x

18.Charles, D., Ahmed, M. N., \& Joshua, O. (2018). Effect of firm characteristics on profitability of listed consumer goods companies in Nigeria. Journal of Accounting, Finance and Auditing Studies, 4(2), 1431. Retrieved from https://www.um.edu.mt/library/oar//handle/123456789/29206

19.Chen, H., \& Wang, X. (2011). Corporate social responsibility and corporate financial performance in China: an empirical research from Chinese firms. Corporate Governance: The International Journal of Business in Society, 11(4), 361-370. https://doi.org/10.1108/14720701111159217

20.Clarkson, M. E. (1995). A stakeholder framework for analyzing and evaluating corporate social performance. Academy of Management Review, 20(1), 92-117. 
https://doi.org/10.5465/amr.1995.9503271994

21.Davenport, K. (2000). Corporate citizenship: A stakeholder approach for defining corporate social performance and identifying measures for assessing it. Business \& Society, 39(2), 210-219. https://doi.org/10.1177/000765030003900205

22.Davis, K. (1973). The case for and against business assumption of social responsibilities. Academy of Management Journal, 16(2), 312-322. https://doi.org/10.5465/255331

23.Dkhili, H., \& Ansi, H. (2012). The link between corporate social responsibility and financial performance: The case of the Tunisian companies. Journal of Organizational Knowledge Management, 2012, 1-12. doi: 10.5171/2012.640106

24.Dunne, T., Roberts, M. J., \& Samuelson, L. (1989). The growth and failure of US manufacturing plants. The Quarterly Journal of Economics, 104(4), 671-698. https://doi.org/10.2307/2937862

25.Freeman, R. E. (2010). Strategic Management: A stakeholder approach. Cambridge, UK: Cambridge University Press.

26.Friedman, M. (1970). The social responsibility of business is to increase its profits the New York Times magazine: The New York Times Company.

27.Ganescu, M.C. (2012). Corporate social responsibility, a strategy to create and consolidate sustainable businesses. Theoretical \& Applied Economics, 19(11), 91- 106. Retrieved from http://store.ectap.ro/articole/799.pdf

28.Gaur, J. (2010). Financial performance measures of business group companies: A study of Indian nonmetallic mineral products industries. IUP Journal of Business Strategy, 7(4), 45. Retrieved from https://www.iupindia.in/1210/IJBS_Financial_Performance_45.html

29.Griffin, J. J., \& Mahon, J. F. (1997). The corporate social performance and corporate financial performance debate: Twenty-five years of incomparable research. Business \& society, 36(1), 5-31. https://doi.org/10.1177/000765039703600102

30.Gurbuz, AO, Aybars, A \& Kutlu, O (2010). Corporate governance and financial performance with a perspective on institutional ownership: empirical evidence from Turkey. Journal of Applied Management Accounting Research, 8(2), 21-37. Retrieved from https://www.cmawebline.org/images/stories/JAMAR_2010_Summer/JAMARv8.2-

Governance_Performance_in_Turkey.pdf

31. Hackston, D., \& Milne, M. J. (1996). Some determinants of social and environmental disclosures in New Zealand companies. Accounting, Auditing \& Accountability Journal, 9(1), 77-108. https://doi.org/10.1108/09513579610109987

32. Haniffa, R. M., \& Cooke, T. E. (2005). The impact of culture and governance on corporate social reporting. Journal of Accounting and Public Policy, 24(5), 391-430. https://doi.org/10.1016/j.jaccpubpol.2005.06.001

33.Hannan, M. T., \& Freeman, J. (1989). Organizational Ecology. Cambridge, UK: Harvard university press.

34.Hull, C. E., \& Rothenberg, S. (2008). Firm performance: The interactions of corporate social performance with innovation and industry differentiation. Strategic Management Journal, 29(7), 781789. https://doi.org/10.1002/smj.675

35.Ilaboya, O. J., \& Ohiokha, I. F. (2016). Firm age, size and profitability dynamics: a test of learning by doing and structural inertia hypotheses. Business and Management Research, 5(1), 29-39. doi:10.5430/bmr.v5n1p29 
36.Johnson, H. L. (1971). Business in contemporary society: Framework and issues. California, USA: Wadsworth Publishing Company.

37.Julizaerma, M. K., \& Sori, Z. M. (2012). Gender diversity in the boardroom and firm performance of Malaysian public listed companies. Procedia-Social and Behavioral Sciences, 65, 1077-1085. https://doi.org/10.1016/j.sbspro.2012.11.374

38.Karaye, Y. I., Ishak, Z., \& Che-Adam, N. (2014). Corporate social disclosure quantity and quality as moderators between corporate social responsibility performance and corporate financial performance. Research Journal of Financial, 5(14), 15-19. Retrieved from http://repo.uum.edu.my/id/eprint/18179

39.Kipesha, E. F. (2013). Impact of size and age on firm performance: evidences from microfinance institutions in Tanzania. Research Journal of Finance and Accounting, 4(5), 105-116. http://hdl.handle.net/20.500.12018/2448

40.Lee, M. D. P. (2008). A review of the theories of corporate social responsibility: Its evolutionary path and the road ahead. International journal of management reviews, 10(1), 53-73. https://doi.org/10.1111/j.1468-2370.2007.00226.x

41.Liargovas, P. G., \& Skandalis, K. S. (2008). Motives and marketing strategies of Greek companies exporting to south-east European markets. South-Eastern Europe Journal of Economics, 6(2), 227244. Retrieved from http://www.asecu.gr/Seeje/issue11/LIARGOVAS.pdf

42. Maignan, I., \& Ferrell, O. C. (2000). Measuring corporate citizenship in two countries: The case of the United States and France. Journal of Business Ethics, 23(3), 283-297. Retrieved from https://link.springer.com/content/pdf/10.1023/A:1006262325211.pdf

43. Malik, A., Liu, J., \& Kyriacou, O. (2011). Creative accounting practice and business performance: evidence from Pakistan. International Journal of Business Performance Management, 12(3), 228-241. Retrieved from https://www.inderscienceonline.com/doi/pdf/10.1504/IJBPM.2011.039888

44.Margaretha, F., \& Supartika, N. (2016). Factors affecting profitability of small medium enterprises (SMEs) firm listed in Indonesia Stock Exchange. Journal of Economics, Business and Management, 4(2), 132-137. doi: 10.7763/JOEBM.2016.V4.379

45.Marimuthu, M., \& Kolandaisamy, I. (2009). Ethnic and gender diversity in boards of directors and their relevance to financial performance of Malaysian companies. Journal of Sustainable Development, 2(3), 139-148. Retrieved from http://eprints.utp.edu.my/12045/

46.McWilliams, A., Siegel, D. S., \& Wright, P. M. (2006). Corporate social responsibility: Strategic implications. Journal of Management Studies, 43(1), 1-18. https://doi.org/10.1111/j.14676486.2006.00580.x

47.Milosevic-Avdalovic, S. (2018). The impact of firm specific factors on the stock prices: Empirical evidence from Belgrade stock exchange. Industrija, 46(2), 7-20. doi: 10.5937/industrija46-15271

48. Mínguez-Vera, A., \& López-Martínez, R. (2010). Female directors and SMES: An empirical analysis. Journal of Global Strategic Management, 8(2), 34-46. doi: 10.20460/JGSM.2010415823

49.Montabon, F., Sroufe, R., \& Narasimhan, R. (2007). An examination of corporate reporting, environmental management practices and firm performance. Journal of Operations Management, 25(5), 998-1014. https://doi.org/10.1016/j.jom.2006.10.003

50.Nahusenay, Simon Ejigu (2016). Determining internal factors affecting financial performance of insurance companies in Ethiopia, The International Journal of Commerce and Behavioral Science. 5(6), 9-21. Retrieved from https://www.theinternationaljournal.org/ojs/index.php?journal=rjcbs\&page=article\&op=view\&path $\% 5 B \% 5 D=4771 \&$ path\%5B\%5D=pdf 
51.Oeyono, J., Samy, M., \& Bampton, R. (2011). An examination of corporate social responsibility and financial performance. Journal of Global Responsibility, 2(1), 100-112. https://doi.org/10.1108/20412561111128555

52.Orlitzky, M., Schmidt, F. L., \& Rynes, S. L. (2003). Corporate social and financial performance: A metaanalysis. Organization Studies, 24(3), 403-441. https://doi.org/10.1177/0170840603024003910

53.Osunsan, O. K., Nowak, J., Mabonga, E., Pule, S., Kibirige, A. R., \& Baliruno, J. B. (2015). Firm age and performance in Kampala, Uganda: A selection of small business enterprises. International Journal of Academic Research in Business and Social Sciences, 5(4), 364-374. doi: 10.6007/IJARBSS/v5-i4/1588

54.Pava, M. L., \& Krausz, J. (1996). The association between corporate social-responsibility and financial performance: The paradox of social cost. Journal of Business Ethics, 15(3), 321-357. Retrieved from https://www.jstor.org/stable/25072758

55.Peloza, J. (2006). Using corporate social responsibility as insurance for financial performance. California Management Review, 48(2), 52-72. https://doi.org/10.2307/41166338

56.Perez, A., \& Del Bosque, I. R. (2013). Measuring CSR image: three studies to develop and to validate a reliable measurement tool. Journal of Business Ethics, 118(2), 265-286. doi 10.1007/s10551-012$1588-8$

57.Peters, R., \& Mullen, M. R. (2009). Some Evidence of the Cumulative Effects of Corporate Social Responsibility on Financial Performance. Journal of Global Business Issues, 3(1), 1-14. Retrieved from https://eds.a.ebscohost.com/eds/pdfviewer/pdfviewer?vid=1\&sid=8ba5627a-76dd-4b37-8e9ecc66bd7fee35\%40sdc-v-sessmgr01

58.Posnikoff, J. F. (1997). Disinvestment from South Africa: They did well by doing good. Contemporary Economic Policy, 15(1), 76-86. https://doi.org/10.1111/j.1465-7287.1997.tb00456.x

59.Preston, L. E., \& O'bannon, D. P. (1997). The corporate social-financial performance relationship: A

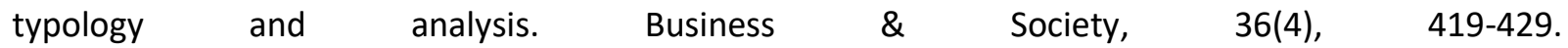
https://doi.org/10.1177/000765039703600406

60.Rajput, N., \& Joshi, B. (2014). Shareholder types, corporate governance and firm performance: An anecdote from Indian corporate sector. Asian Journal of Finance \& Accounting, 7(1), 45-63. https://doi.org/10.5296/ajfa.v7i1.6070

61. Reverte, C. (2009). Determinants of corporate social responsibility disclosure ratings by Spanish listed firms. Journal of Business Ethics, 88(2), 351-366. doi: 10.1007/s10551-008-9968-9

62.Roman, R. M., Hayibor, S., \& Agle, B. R. (1999). The relationship between social and financial performance: Repainting a portrait. Business \& Society, 38(1), 109-125. https://doi.org/10.1177/000765039903800105

63.Rouf, D. (2011). The corporate social responsibility disclosure: A study of listed companies in Bangladesh, Business and Economics Research Journal, (2)3, 19-32. Retrieved from https://papers.ssrn.com/sol3/papers.cfm?abstract_id=2568479

64.Schreck, P. (2011). Reviewing the business case for corporate social responsibility: New evidence and analysis. Journal of Business Ethics, 103(2), 167. doi: 10.1007/s10551-011-0867-0

65.Shane, P. B., \& Spicer, B. H. (1983). Market response to environmental information produced outside the firm. The Accounting Review, 58(3), 521-538.

Retrieved from https://www.jstor.org/stable/246532

66.Sidhu, H. S., \& Bhatia, G. (1993). Factors affecting profitability in Indian textile industry. Indian Economic Journal, 41(2), 137. Retrieved from 
https://search.proquest.com/openview/0c7fd4a28c27467504201b5375127815/1?pqorigsite=gscholar\&cbl=1819379

67.Silberhorn, D., \& Warren, R. C. (2007). Defining corporate social responsibility: A view from big companies in Germany and the UK. European business review, 19(5), 352-372. https://doi.org/10.1108/09555340710818950

68.Simms, J. (2002). Business: Corporate social responsibility-you know it makes sense. Accountancy, 130(1311), 48-48. Retrieved from https://www.accountancydaily.co/corporate-social-responsibilityyou-know-it-makes-sense

69.Smith, A.D. (2007). Making the case for the competitive advantage of corporate social responsibility. Business Strategy Series, 8(3), 186-195. https://doi.org/10.1108/17515630710684187

70.Smith, K. (2002). ISO considers corporate social responsibility standards. The Journal for Quality and Participation, 25(3), 42. Retrieved from https://search.proquest.com/openview/c87cd0d0437ecc449b879b2af7b71fb1/1?pqorigsite $=$ gscholar $\& \mathrm{cbl}=37083$

71.Stanwick, P. A., \& Stanwick, S. D. (1998). The relationship between corporate social performance, and organizational size, financial performance, and environmental performance: An empirical examination. Journal of Business Ethics, 17(2), 195-204. Retrieved from https://link.springer.com/content/pdf/10.1023/A:1005784421547.pdf

72.Story, J., Castanheira, F., \& Hartig, S. (2016). Corporate social responsibility and organizational attractiveness: implications for talent management. Social Responsibility Journal. 12(3), 484-505. https://doi.org/10.1108/SRJ-07-2015-0095

73.Sturdivant, F. D., \& Ginter, J. L. (1977). Corporate social responsiveness: Management attitudes and economic performance. California Management Review, 19(3), 30-39. https://doi.org/10.2307/41164709

74.Tsang, E. W. (1998). A longitudinal study of corporate social reporting in Singapore. Accounting, Auditing \& Accountability Journal, 2(5), 624-635. https://doi.org/10.1108/09513579810239873

75.Valmohammadi, C. (2014). Impact of corporate social responsibility practices on organizational performance: an ISO 26000 perspective. Social Responsibility Journal, 10(3), 455-479. https://doi.org/10.1108/SRJ-02-2013-0021

76.Villalonga, B., and Amit, R. (2006). How do family ownership, control and management affect firm value? Journal of Financial Economics, 80(2), 385-417. https://doi.org/10.1016/j.jfineco.2004.12.005

77.Waddock, S. A., \& Graves, S. B. (1997). The corporate social performance-financial performance link. Strategic Management Journal, 18(4), 303-319. https://doi.org/10.1002/(SICl)10970266(199704)18:4<303::AID-SMJ869>3.0.CO;2-G

78.Wartick, S. L., \& Cochran, P. L. (1985). The evolution of the corporate social performance model. Academy of Management Review, 10(4), 758-769. https://doi.org/10.5465/amr.1985.4279099

79.Weber, M. (2008). The business case for corporate social responsibility: A company-level measurement approach for CSR. European Management Journal, 26(4), 247-261. https://doi.org/10.1016/j.emj.2008.01.006

80.Weiser, J., \& Zadek, S. (2000). Conversations with disbelievers: The business case for corporate social responsibility. NY, USA: Brody \& Weiser for the Ford Foundation. https://bwbsolutions.com/wpcontent/uploads/convdisb.pdf

81. Wood, D. J. (1991). Corporate social performance revisited. Academy of Management Review, 16(4), 691-718. https://doi.org/10.5465/amr.1991.4279616 
82.Wright, P., \& Ferris, S. (1997). Agency conflict and corporate strategy: The effect of divestment on corporate value. Strategic Management Journal, 18 (1), 77-83. https://doi.org/10.1002/(SICI)10970266(199701)18:1<77::AID-SMJ810>3.0.CO;2-R

83.Yasuda, T. (2005). Firm growth, size, age and behavior in Japanese manufacturing. Small Business Economics, 24(1), 1-15. Retrieved from https://link.springer.com/content/pdf/10.1007/s11187-0057568-y.pdf

84.Zulfiqar, S. (2016). Link between Corporate Philanthropy and Corporate Financial Performance: Evidence from Pakistani Textile Sector. International Journal of Engineering and Management Sciences, 1(1), 1-12. https://doi.org/10.21791/IJEMS.2016.1.47. 